UDC: $159.942+372.3+159.9 .07(560)$

DOI: DOI: https://doi.org/10.24195/2414-4665-2017-3-9

\author{
Ali Özcan, \\ instructor, Department of Child Care and Youth Services, \\ Ceyhun Ersan, \\ instructor, Department of Child Care and Youth Services, \\ Tuncay Oral,
}

PhD (Counseling Psychological and Guidance), instructor, Department of Child Care and Youth Services,

Pamukkale University,

Çamlaralti Mahallesi, University Cd., 11/A, Denizli, Turkey

\title{
EMOTION REGULATION IN PRESCHOOL PERIOD: ACADEMIC RESEARCHES IN TURKEY
}

The study aims to investigate research studies conducted in Turkey from 1996 to 2016 on the emotion regulation in preschool period. Within the scope of the present study 10 Master's and 1 Doctoral theses as well as 3 research papers have been found. The theses and research papers were classified according to the years when the studies were conducted, to the research type, research design, data collection tools, methods and the cities where the data were collected. The theses were gathered from the thesis centre of Council of Higher Education and the research papers were obtained through the index scanning of Google Scholar, Ulakbim-Journal Park, Taylor\&Francis Online, Science Direct, Web of Science, Academic Search Complete and ERIC. This study was performed using epistemological document analysis method. Descriptive statistics such as frequency and percentage were made use of for the distribution according to the year when Master's and Doctoral theses and the research papers were performed and the methods and techniques used. According to the research results, it is observed that studies carried out on the emotion regulation skills in preschool period in our country have not reached a desired level yet; this issue still remains understudied. As a contribution to the field, it is suggested to include the issue of emotion regulation in the master's and doctoral theses. In pre-school period, validity-reliability studies can be carried out by developing different measurement tools to examine emotion regulation skills of children. Also intercultural studies in which the emotion regulation skills of children in different countries are compared to emotion regulation skills of children in our country might be performed.

Keywords: preschool period, emotion regulation, Master's and Doctoral thesis, scientific articles, research studies in Turkey.

\section{Introduction}

The word "emotion" refers to a strong mental reaction involuntarily taking place in the brain in response to stimuli and influences from the outside world, as a correspondent to the words "expression, visualization and excitement" [9]. Although considering the emotion only as a feeling is something that is more appealing to people, this important concept that concerns both the body and mind, with the expressions such as "I feel happy" or "I feel angry", requires a more inclusive definition. In this context, if a definition of emotion should be made it can be expressed as the physiological stimulations, feelings, cognitive processes, visible manifestations, and the complex pattern of physical and mental changes involving specific behavioural reactions made in response to situations perceived to be personally significant [5].

Contemporary theories emphasize that emotions affect decision making and social relations by preparing physical and psychological reactions [7]. Beginning from the early childhood, children's personality and emotional perceptions are significantly developing. Such forms of emotional behaviours of children as smiling, crying, and curiosity play a significant role in directing the behaviours of other people. Likewise, the emotional reactions of other people make children's social behaviours to have a certain pattern [1]. If emotions do not occur in appropriate forms, together with being functional, for example, if they are experienced in an intense way, if they are long-term, or incompatible with the current situations, they can be problematic for the people [11].

It is seen that the concept of emotion regulation, which has very important effects on the social and emotional development of the individual, is considered differently in the scientific literature. In one of these definitions, emotion regulation is individual's observation, evaluation, and regulation of emotional reactions in order to reach the object of his/her desires. There are various types of reactions in cognitive, social, behavioural and physiological dimensions in emotion regulation behaviour. Such reactions as considering things worse than they actually are, and blaming oneself or others are at the cognitive scale, seeking help from outside is at the social one, shouting out loud and crying are at behavioural scale, and faster heartbeat and difficulty in breathing are at the physiological one [4]. In another definition, emotion regulation is the ability to reveal, stop, or sustain the positive or negative reactions to different situations. The observation of children waiting for a desired object as an activity, 
which can be considered in the context of postponement of the pleasure, provides extremely valuable information about their emotional and behavioural skills [6].

Emotions can bring people together or separate them, but if they control their emotions they will be able to live in peace. Those who learn the ways of recognizing and managing their emotions and turning them into positive ones in any kind of relations, culture and traditions, as family or the society members, will definitely have no problems in their social life [9]. It should be mentioned that children who are good at managing their emotions can help others in stressful moments. However, children who are weak in regulating their emotions often show less positive social behaviour [1]. Since the concept of emotion regulation is related to social competence, it has important effects on the socialization of a child. It is because children with high social skills and who are able to cooperate with their parents and people in their immediate circle as a rule have better developed emotion regulation skills. In the following years, the emotion regulation will also be related to the psychological status of the grown up person. It is because of the fact that negativity in the acquisition of emotion regulation skills can negatively affect the competences in other development areas. Even in the pre-school period, children with inadequate emotion regulation skills are in the high risk group regarding having depression and aggressive behaviour [10].

The examination of the studies on the emotion regulation skills of pre-school children over the last 10 years has shown that most of them have been made by the foreign researchers. Although the investigations on emotion regulation skills of pre-school children in Turkey have been developing in recent years, this issue still remains understudied here.

The paper aims to investigate the academic researches on emotion regulation skills in pre-school period in Turkey during the 20 years period (from 1996 to 2016). Regarding this purpose, it is supposed that this study can attract the researchers' attention to the subject of emotion regulation skills in the pre-school period and guide those who are interested in it and want to carry out research studies on the topic.

\section{Research methods}

\section{Model of the Research}

The research is a screening study in descriptive characteristics, aimed at examining graduate and doctoral dissertations and articles on emotion regulation skills in pre-school period in Turkey over the 20 years period (from 1996 to 2016) [3]. Since the thesis and the articles are intended to be evaluated using specific criteria, this research is also a qualitative study based on document analysis.

\section{Scope of the Study}

10 graduate theses, 1 doctorate thesis, 3 articles on emotion regulation skills in pre-school period constitute the scope of this research. Academic researches to be included in the study were searched using the keywords "emotion regulation" (duygu düzenleme) and "emotional regulation" (duygusal düzenleme). The theses have been obtained from the National Dissertation Centre of the Higher Education Council (http//tez.yok.gov.tr/UlusalTezMerkezi). The articles have been found by scanning Google Scholar, UlakbimMagazine Park, Taylor\&Francis Online, Science Direct, Web of Science, Academic Search Complete and ERIC indexes.

\section{Data Collection and Analysis}

An epistemological document analysis method was used in the research [8]. The full texts of the theses and the articles have been transferred to the computer environment in pdf format by applying the above mentioned criteria. The theses and articles have been examined in detail, and in the distribution of the theses and articles investigated, the frequency and percent distribution from the descriptive analysis methods have been utilized [2].

\section{Results}

In Table 1 one can see the distribution of the studies covering the emotion regulation skills in pre-school period in Turkey according to years. According to the research results, there are 14 scientific researches related to the subject in the period of 20 years. 10 of these 14 $(71.43 \%)$ are graduate thesis, $1(7.14 \%)$ is doctoral thesis, and $3(21.43 \%)$ are scientific papers. The distribution ratios have shown that 2010 and 2016 are considered to be the years in which the greatest number of the related Master's theses was performed. One study was conducted in each of the years of 2006, 2013, 2014 and 2015, and no studies were found in other years. In the year 2015, only 1 doctoral dissertation was prepared, and no studies were found in other years. Three articles have been found ( 2 papers written in 2015, and 1 in 2016).

According to the Table 2, the research of Aktürk (2016), among the Master's theses regarding emotion regulation in pre-school period between 1996 and 2016, was carried out by experimental research method. All other Master's theses were performed by the scanning model. The review of the research samples in the examined Master's theses has shown that the studies involved pre-school students, their mothers and teachers. The examination of the survey instruments used in the studies has shown that at least two and maximum four scales were used in each research.

According to the Table 3, it can be seen that only one doctoral dissertation, which is focused on emotion regulation skills in pre-school period, was prepared within 20 years (from 1996 to 2016). In the sample of Sahin's (2015) screening model research study, which investigated whether executive functions and emotion regulation skills differed according to the attachment patterns of 6 year-old children, 137 children at the age of 6 were included. Three scales were used in it. 
Table 1.

Yearly Distribution of the Studies Carried Out on Emotion Regulation Skills in Pre-School Period in Turkey

\begin{tabular}{|c|c|c|c|c|c|c|}
\hline \multirow{2}{*}{ Year } & \multicolumn{2}{|c|}{ Master's Thesis } & \multicolumn{2}{c|}{ Doctoral Thesis } & \multicolumn{2}{c|}{ Article } \\
\cline { 2 - 7 } & $\mathbf{n}$ & $\mathbf{\%}$ & $\mathbf{n}$ & $\boldsymbol{\%}$ & $\mathbf{n}$ & 0.0 \\
\hline 1996 & - & 0.0 & - & 0.0 & - & 0.0 \\
\hline 1997 & - & 0.0 & - & 0.0 & - & 0.0 \\
\hline 1998 & - & 0.0 & - & 0.0 & - & 0.0 \\
\hline 1999 & - & 0.0 & - & 0.0 & - & 0.0 \\
\hline 2000 & - & 0.0 & - & 0.0 & - & 0.0 \\
\hline 2001 & - & 0.0 & - & 0.0 & - & 0.0 \\
\hline 2002 & - & 0.0 & - & 0.0 & - & 0.0 \\
\hline 2003 & - & 0.0 & - & 0.0 & - & 0.0 \\
\hline 2004 & - & 0.0 & - & 0.0 & - & 0.0 \\
\hline 2005 & - & 0.0 & - & 0.0 & - & 0.0 \\
\hline 2006 & 1 & 10 & - & 0.0 & - & 0.0 \\
\hline 2007 & - & 0.0 & - & 0.0 & - & 0.0 \\
\hline 2008 & - & 0.0 & - & 0.0 & - & 0.0 \\
\hline 2009 & - & 0.0 & - & 0.0 & - & 0.0 \\
\hline 2010 & 3 & 30 & - & 0.0 & - & 0.0 \\
\hline 2011 & - & 0.0 & - & 0.0 & - & 0.0 \\
\hline 2012 & - & 0.0 & - & 0.0 & - & 0.0 \\
\hline 2013 & 1 & 10 & - & 0.0 & - & 0.0 \\
\hline 2014 & 1 & 10 & - & 100.0 & 2 & 66.66 \\
\hline 2015 & 1 & 10 & 1 & 0.0 & 1 & 33.33 \\
\hline 2016 & 3 & 30 & - & 100.0 & 3 & 100.0 \\
\hline Total & 10 & 100.0 & 1 & & & \\
\hline
\end{tabular}

Table 2.

\begin{tabular}{|c|c|c|c|}
\hline $\begin{array}{l}\text { Researcher / } \\
\text { Year / Prov- } \\
\text { ince }\end{array}$ & Name of the Thesis & Method / Sample & Measuring Tools \\
\hline $\begin{array}{l}\text { Altan, Ö. } \\
2006 \\
\text { Istanbul }\end{array}$ & $\begin{array}{l}\text { Maternal socialization and the effect } \\
\text { of the child's temperament on the } \\
\text { child's emotion regulation skills }\end{array}$ & \begin{tabular}{|l|} 
Scanning Model \\
145 children at the ages \\
between 4 and 6, their \\
mothers and teachers
\end{tabular} & $\begin{array}{l}\text { Emotion regulation Skills Scale } \\
\text { Pleasure Postponing Skill Test } \\
\text { Coping with Negative Feelings Scale } \\
\text { Child Breeding Inventory }\end{array}$ \\
\hline $\begin{array}{l}\text { Kurbet, H. } \\
2010 \\
\text { Ankara }\end{array}$ & $\begin{array}{l}\text { Examining the emotion regulation } \\
\text { skills of the pre-school children and } \\
\text { their mothers' empathic tendencies } \\
\text { and attitudes }\end{array}$ & $\begin{array}{l}\text { Scanning Model } \\
\text { A total of } 277 \text { children } \\
\text { aged from } 5 \text { to } 6, \text { con- } \\
\text { sisted of } 133 \text { girls and } \\
144 \text { boys, and their } \\
\text { mothers }\end{array}$ & $\begin{array}{l}\text { Children's Feelings Rating Scale } \\
\text { Empathic Tendency Scale } \\
\text { Family Attitude and Behaviour Scale } \\
\text { Family Information Form }\end{array}$ \\
\hline $\begin{array}{l}\text { Metin, I. } \\
2010 \\
\text { Istanbul }\end{array}$ & $\begin{array}{l}\text { Anger / anger tendency, self-control } \\
\text { skills, and the effect of mother's sen- } \\
\text { sitivity to the emotion regulation } \\
\text { skills of Turkish pre-school children }\end{array}$ & $\begin{array}{l}\text { Scanning Model } \\
118 \text { children aged 3-6 } \\
\text { years, mothers and } \\
\text { kindergarten teachers }\end{array}$ & $\begin{array}{l}\text { Emotion regulation Skills Scale } \\
\text { Self-Control Ability Scale } \\
\text { Maternal Child's Sensitivity Scale }\end{array}$ \\
\hline $\begin{array}{l}\text { Sen, H. } \\
2010 \\
\text { Istanbul }\end{array}$ & $\begin{array}{l}\text { Could the speed of recovery be in- } \\
\text { dicative of emotion regulation? }\end{array}$ & $\begin{array}{l}\text { Scanning Model } \\
67 \text { children between } \\
3,6-7,0 \text { years and } \\
\text { mother }\end{array}$ & $\begin{array}{l}\text { Behavioural Batteries } \\
\text { Emotion Regulation Scale } \\
\text { MacArthur Health and Behaviour } \\
\text { Survey }\end{array}$ \\
\hline $\begin{array}{l}\text { Mustafaoğlu, } \\
\text { N. } 2013 \\
\text { Istanbul }\end{array}$ & $\begin{array}{l}\text { The role of mother's strategies in the } \\
\text { child's emotion regulation in case of } \\
\text { postponing the pleasure }\end{array}$ & \begin{tabular}{|l|} 
Scanning Model \\
62 children between $19-$ \\
34 months and their \\
mothers
\end{tabular} & $\begin{array}{l}\text { General information form } \\
\text { Mother's Emotion Regulation Strate- } \\
\text { gies Scale }\end{array}$ \\
\hline
\end{tabular}




\begin{tabular}{|c|c|c|c|}
\hline $\begin{array}{l}\text { Researcher / } \\
\text { Year / Prov- } \\
\text { ince }\end{array}$ & Name of the Thesis & Method / Sample & Measuring Tools \\
\hline $\begin{array}{l}\text { Ertan, N. N. } \\
2014 \\
\text { Istanbul }\end{array}$ & $\begin{array}{l}\text { Investigation of the relationship be- } \\
\text { tween "emotion regulation" and "cop- } \\
\text { ing strategies" of pre-school children } \\
\text { through "self-monitoring through } \\
\text { effort" }\end{array}$ & $\begin{array}{l}\text { Scanning Model } \\
\text { A total of } 45 \text { children } \\
\text { consisted of } 25 \text { girls } \\
\text { and } 20 \text { boys, aged be- } \\
\text { tween } 4 \text { and } 6 \text { years. }\end{array}$ & $\begin{array}{l}\text { Emotion Regulation Scale } \\
\text { Pre-school Age Coping Scale for } \\
\text { Children } \\
\text { Self-monitoring Through Effort Bat- } \\
\text { tery }\end{array}$ \\
\hline $\begin{array}{l}\text { Kayhan Ak- } \\
\text { türk, Ş. } \\
2015, \\
\text { Istanbul }\end{array}$ & $\begin{array}{l}\text { Examination of emotion regulation } \\
\text { skills and peer relations in pre-school } \\
\text { children }\end{array}$ & $\begin{array}{l}\text { Scanning Model } \\
880 \text { pre-school children } \\
\text { and their teachers }\end{array}$ & $\begin{array}{l}\text { Personal Information Form, } \\
\text { Emotional Adjustment Scale } \\
\text { Ladd-Profilet Child Behaviour Scale }\end{array}$ \\
\hline $\begin{array}{l}\text { Akturk, B. } \\
2016 \\
\text { Osmaniye }\end{array}$ & $\begin{array}{l}\text { The effect of game-based psychoedu- } \\
\text { cation program on the level of emo- } \\
\text { tion regulation skills of pre-school } \\
\text { children with divorced parents }\end{array}$ & $\begin{array}{l}\text { Experimental Model } \\
24 \text { kindergarten stu- } \\
\text { dents consisted of } 12 \\
\text { girls and } 12 \text { boys }\end{array}$ & $\begin{array}{l}\text { Children's Emotional Rating Scale } \\
\text { Personal Information Form }\end{array}$ \\
\hline $\begin{array}{l}\text { Erel, S. } \\
2016 \\
\text { Ankara }\end{array}$ & $\begin{array}{l}\text { Ability to take perspective on pre- } \\
\text { school children, relationship of emo- } \\
\text { tion regulation and moral develop- } \\
\text { ment with behavioural problems }\end{array}$ & $\begin{array}{l}\text { Scanning Model } \\
123 \text { children aged from } \\
4 \text { to } 6 \text { years and parents } \\
\text { of these children }\end{array}$ & $\begin{array}{l}\text { Denham Emotion Understanding Task } \\
\text { Test } \\
\text { The Moral Dilemma Test } \\
\text { Emotion Regulation Scale } \\
\text { Hacettepe Spiritual Consistence Scale }\end{array}$ \\
\hline $\begin{array}{l}\text { Işık Uslu, A.E. } \\
2016 \\
\text { Ankara }\end{array}$ & $\begin{array}{l}\text { Evaluation of the mothers' beliefs } \\
\text { about children's emotions and the } \\
\text { relationship between the child's emo- } \\
\text { tion regulation skills, and the moth- } \\
\text { ers' emotional talks to the children }\end{array}$ & $\begin{array}{l}\text { Scanning Model } \\
50 \text { children aged from } 4 \\
\text { to } 6 \text { years, who receive } \\
\text { pre-school education, } \\
\text { and their mothers }\end{array}$ & $\begin{array}{l}\text { General Information Form } \\
\text { Parents' Beliefs about Children's } \\
\text { Feelings Scale Children's Feelings } \\
\text { Rating Scale }\end{array}$ \\
\hline
\end{tabular}

Table 3.

Ph.D. Master's Theses Related to the Skills of Emotion Regulation in Pre-School Period in Turkey

\begin{tabular}{|l|l|l|l|}
\hline $\begin{array}{c}\text { Researcher / } \\
\text { Year / Province }\end{array}$ & \multicolumn{1}{|c|}{ Name of the Thesis } & \multicolumn{1}{c|}{ Method / Sample } & \multicolumn{1}{c|}{ Measuring Tools } \\
\hline $\begin{array}{l}\text { Sahin, G. } \\
2015 \\
\text { Eskisehir }\end{array}$ & $\begin{array}{l}\text { Examination of executive func- } \\
\text { tions of pre-school children and } \\
\text { emotion regulation skills in } \\
\text { terms of attachment patterns }\end{array}$ & $\begin{array}{l}\text { Scanning Model } \\
\text { A total of 137 students, } \\
\text { consisting of 70 girls and } \\
67 \text { boys, in the age group } \\
\text { of } 6\end{array}$ & $\begin{array}{l}\text { Tncomplete Toy Baby Stories } \\
\text { Selection } \\
\text { Pre-School Self-Regulation Scale }\end{array}$ \\
\hline
\end{tabular}

Articles Related to the issue of Emotion Regulation Skills in Pre-school Period in Turkey

\begin{tabular}{|c|c|c|c|}
\hline $\begin{array}{c}\text { Researcher / } \\
\text { Year / Province }\end{array}$ & Name of the Article & Method / Sample & Measuring Tools \\
\hline \begin{tabular}{|l|} 
Koçyiğit, Y1lmaz \\
and Sezer, \\
2015 \\
Erzurum \\
\end{tabular} & $\begin{array}{l}\text { Investigation of the relationship } \\
\text { between social competence and } \\
\text { emotion regulation skills and play- } \\
\text { ing skills of } 60-72 \text { month old chil- } \\
\text { dren }\end{array}$ & $\begin{array}{l}\text { Scanning Model } \\
228 \text { children of } 60-72 \\
\text { months. }\end{array}$ & $\begin{array}{l}\text { Social Competence and Behav- } \\
\text { ioral Assessment Scale } \\
\text { Emotion Regulation Scale } \\
\text { Game Skills Assessment Scale }\end{array}$ \\
\hline $\begin{array}{l}\text { Ecirli and Ogel- } \\
\text { man, } 2015 \\
\text { Denizli }\end{array}$ & $\begin{array}{l}\text { The validity-reliability study of the } \\
\text { emotion regulation strategies scale } \\
\text { for children aged } 5 \text { to } 6 \text { years }\end{array}$ & $\begin{array}{l}\text { Scanning Model } \\
70 \text { children of 5-6 } \\
\text { years. }\end{array}$ & $\begin{array}{l}\text { Scale of Emotion Regulation } \\
\text { Strategies }\end{array}$ \\
\hline $\begin{array}{l}\text { Ar1 and Yaban, } \\
2016 \\
\text { Ankara }\end{array}$ & $\begin{array}{l}\text { Social behaviors of children in the } \\
\text { pre-school period: the role of tem- } \\
\text { perament and emotion regulation }\end{array}$ & $\begin{array}{l}\text { Scanning Model } \\
250 \text { children of } 4-5-6 \\
\text { years, their mothers } \\
\text { and teachers }\end{array}$ & $\begin{array}{l}\text { Short Temperament Scale for } \\
\text { Children } \\
\text { Child Emotional Rating Scale } \\
\text { Pre-school Social Behavior Scale }\end{array}$ \\
\hline
\end{tabular}


According to the Table 4, three articles regarding emotion regulation skills in pre-school period were written over the period between 1996 and 2016. All three of these research studies were performed by screening model. It is seen that the selected samples in the articles involved pre-school students, their mothers and teachers. At least one-maximum three scales were used in the studies.

\section{Conclusions}

The Master's theses, doctoral dissertations and articles in the field of emotion regulation skills in the preschool period written/prepared in Turkey from 1996 to 2016, covering 20 years, constitute the scope of this study. When the studies related to the subject were examined, we have found that 10 Master's theses, 1 doctoral dissertation and 3 articles were written within the period of 20 years from 1996 until today.

The examination of the research studies in terms of the research models has shown that all but one were carried out by the scanning method. The only study was performed by the experimental one. No qualitative or longitudinal studies on emotion regulation skills have been identified. It is thought that a comprehensive evaluation of the development of the emotion regulation skills of children particularly with the longitudinal research methodology will be very useful for parents, teachers and researchers. The examination of the scientific works in the field has demonstrated the small number of research studies were performed by Turkish scholars. For this reason, it may be suggested to carry out researches in the different topics that have not been studied before, involving the emotional regulation skills in the pre-school period (prosocial behaviours and emotion regulation skills, moral development and emotion regulation skills, children with special needs and their emotion regulation skills, gifted children and their emotion regulation skills, peer violence exposure and emotion regulation skills, etc.).

It is interesting that most of the analysed research studies were performed in big cities of the western part of Turkey. It is considered that the studies involving emotion

\section{REFERENCES}

1.Berk, L. E. (2013). Çocuk gelişimi [Child development]. Ankara: İmge Kitabevi [in Turkish].

2.Büyüköztürk, Ş. (2016). Sosyal bilimler için veri analizi el kitabu [Data analysis handbook for social sciences]. Ankara: Pegem Akademik Yayıncılık [in Turkish].

3.Büyüköztürk, Ş., Kılıç Çakmak, E., Akgün, Ö. E., Karadeniz, Ş. \& Demirel, F. (2013). Bilimsel araştırma yöntemleri [Scientific research methods]. Ankara: Pegem Akademi [in Turkish].

4.Garnefski, N., Kraaij, V. \& Spinhoven, P. (2001). Negative life events, cognitive emotion regulation and emotional problems. Personality and Individual Differences, 30(8), 1311-1327 [in English]. regulation skills in small and large settlements in different regions of our country will also have positive results in terms of the field development. Besides, the designing of educational programs considering the geographical, socioeconomic and cultural characteristics of the regions are of great importance in terms of emotional development of pre-school children as well as the development of their positive feelings towards themselves, other people and the whole world.

From the moment the child arrives to the world, he/she develops rapidly in physical, mental, social and emotional aspects as a result of the interaction with the environment. The period from 0 to 6 years is one of the critical ones in human life, in which the foundations of the personality are laid and the child is highly affected by the immediate circle and is open to all kinds of learning [12]. For this reason, the issue of the emotion regulation skills, which is a particular concern to both an individual and the society, can be taught to the pre-school teachers in inservice training programs that are to be organized. The students who study at Pre-school Teachers and Child Development and Education Departments at Universities can be taught to prepare programs that will contribute to the development of the emotion regulation skills in children.

Family has one of the most important effects on all areas of child's development (including the emotional development). For this reason, studies on emotional development and emotion regulation skills in pre-school period may include topics such as parent education, family participation, and school-family cooperation. Intercultural studies in which the emotion regulation skills of children in different countries are compared to emotion regulation skills of children in our country might be performed. In pre-school period, validity-reliability studies can be carried out by developing different measurement tools to measure emotion regulation skills of children. Due to all these mentioned reasons, numerous additional researches are needed on the subject of emotion regulation skills in pre-school period.

5.Gerrig, J. R. \& Zimbardo, P. G. (2013). Psikoloji ve yaşam [Psychology and life]. Ankara: Nobel Akademik Yayıncılık [in Turkish].

6.Grolnick, W. S., Bridges, L. J. \& Connell, J. P. (1996). Emotion regulation in two-year-olds: Strategies and emotional expression in four contexts. Child Development, 67(3), 928-941 [in English].

7.Gross, J. J. \& Thompson, R. A. (2007). Emotion regulation: Conceptual foundations. J. J. Gross (Eds.), CALL Handbook of emotion regulation (pp. 3-24). New York: Guilford Press [in English].

8.Karadağ, E. (2009). Eğitim bilimleri alanında yapılmış doktora tezlerinin tematik açıdan incelemesi [Thematic examination of doctoral dissertations in educational sciences]. Ahi Evran Üniversitesi Kırşehir Eğitim 
Fakültesi Dergisi - Ahi Evran University Kirşehir Education Faculty Journal, 10(3), 75-87 [in Turkish].

9.Mayes, C. L. \& Cohen, J. D. (2006). Yale Üniversitesi Çocuk Araştırma Merkezi çocuğunuzu anlama rehberi [Yale University Children's Research Center as a guide to understanding the child]. İstanbul: Beyaz Balina Yayınları [in Turkish].

10. Thompson, R. A., Meyer, S. \& Jochem, R. (2008). Emotion regulation. Elsevier Inc. Publishing [in English].
11.Werner, E. E. \& Gross, J. J. (2009). Emotion regulation and psychopathology. A.M. Kring, D.M. Sloan (Eds.), CALL Emotion Regulation and Psychopathology (pp. 13-38). New York: Guilford Press [in English].

12.Zembat, R. \& Unutkan, P. Ö. (2001). Okul öncesi dönemde çocuğun sosyalleşmesinde ailenin yeri [The place of family in the socialization of the child in preschool period]. İstanbul: Ya-Pa Yayınları [in Turkish].

$$
\begin{array}{r}
\text { Алі Озкан, } \\
\text { викладач кафедри дошкільної освіти, } \\
\text { Ерсан Дожейхун, } \\
\text { викладач кафедри дошкільної освіти, } \\
\text { Тунчай Орал, } \\
\text { кандидат наук (психологическое консультирование), } \\
\text { викладач кафедри дошкільної освіти, } \\
\text { Університет Памуккале, } \\
\text { м. Денізлі, Туреччина }
\end{array}
$$

\section{ПРОБЛЕМА ЕМОЦІЙНОЇ РЕГУЛЯЦІЇ ДОШКІЛЬНИКІВ У НАУКОВИХ ДОСЛІДЖЕННЯХ ТУРЕЧЧИНИ}

У статті здійснено аналіз наукових робіт за період з 1996 до 2016 рр. з проблем емоційної регуляції дошкільників. Загалом було знайдено та проаналізовано 10 магістерських, 1 докторську (кандидатську) дисертації та 3 наукові статті. Усі знайдені роботи було класифіковано за роком та місцем проведення, типом та методами дослідження. Дисертації з теми емоційної регуляції було отримано з Дисертаційного центру Департаменту вищої освіти, а статті було знайдено за допомогою сканування Google Scholar, Ulakbim-Journal Park, Taylor\&Francis Online, Science Direct, Web of Science, Academic Search Complete and ERIC. За результатами проведеного дослідження можна зробити висновок, що у Туреччині проблема емоційної регуляції дошкільників вивчена на недостатньому рівні та потребує пильної уваги до себе з боку дослідників. Пропонується включити цю тему в якості предмету дослідження до магістерських та докторських (кандидатських) дисертацій. Окрім цього, слід проводити дослідження шляхом розробки інструментів для визначення емоційної регуляції дітей, а також порівняльні дослідження особливостей розвитку навичок емоційної регуляції дітей Туреччини та інших країн. Особливості емоційної регуляції дітей мають розглядатися в рамках спеціально організованих курсів для діючих учителів початкових класів. Студентів, які навчаються на факультетах дошкільного виховання, варто навчати розробляти програми для розвитку у дітей навичок емоційної регуляції. Відомо, що родина має найбільший вплив на розвиток дитини, отже пропонується в рамках вивчення проблем емоційної регуляції також розглядати такі теми, як родинне виховання, взаємодія учителів і батьків тощо.

Ключові слова: дошкільний період, емоційна регуляція, магістерська дисертація, докторська дисертація, наукові дослідження, Туреччина.

Submitted on 16, February, 2017 